\title{
Other Duties as As igned: Emergin Trends in the Academic Library Job Market
}

\section{Penny M. Beile and Megan M. Adams}

Nine hundred job announcements published in four journals in 1996 were examined using content analysis to compare requirements and benefits among various positions in academic libraries. This study updates the article "The Academic Library Job Market: A Content Analysis Comparing Public and Technical Services," in which authors David W. Reser and Anita P. Schuneman analyzed 1,133 job advertisements published in 1988 to compare public and technical services positions. ${ }^{1}$ A growing number of electronic-related advertisements in the past decade has led to the addition of a third division to be investigated, namely the systems and automation librarian. For purposes of comparison with Reser and Schuneman's article, the authors retained the same research design and variables. These variables include levels of computer skills, foreign-language requirements, previous work experience, educational requirements, and minimum salary offered.

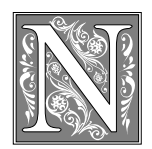

umerous publications analyzing position announcements as early as the 1950s have used content analysis to document changes in the library job market and requirements and benefits for librarians. Many of these studies tracked the impact of only a single variable, such as technology, or researched a specific position, such as catalogers or systems librarians. A thorough review of the literature did not reveal any studies investigating the full spectrum of academic librarian positions in the 1990s. This study expands the scope of previous research by analyzing differences among public, technical, and systems positions in 1996. In addition, data from this study are compared with previous research to discern changes in the academic library job market. The results of this study should be of interest to library science students considering an area of specialization, to library schools when designing curricula to support needs of academic libraries and trends in employment, and to librarians and administrators interested in learning more about the academic library job market.

Penny M. Beile is Head, Curriculum Materials Center, in the University of Central Florida Libraries; email: pbeile@mail.ucf.edu. Megan M. Adams is the Social Sciences Librarian in McCabe Library at Swarthmore College; e-mail: madams1@swarthmore.edu. The authors wish to thank the Friends of Louisiana State University Libraries for a stipend that helped finance research assistance from Eric Holt, the Inter-Library Loan Department at the University of Central Florida Libraries for supplying materials necessary to complete this project, and Thomas A. O'Neil, Florida Fish and Wildlife Conservation Commission, who provided invaluable assistance in the statistical analysis of data. 


\section{Review of the Literature}

A number of previous studies used information contained in position announcements as the basis for investigation of the academic library job market and benefits and requirements of those advertised positions. Most of these studies tended to be very specific, focusing on individual job titles and positions. Several other studies traced the impact of automation on requirements and qualifications for academic librarians. A limited number of studies analyzed job advertisements for multiple position titles.

Kenneth Furuta examined all advertisements for cataloging positions in American Libraries published from 1970 to 1989. He concluded that automation and bibliographic utilities contributed to a reduction in the number of catalogers. ${ }^{2}$ Michael Towsey studied job advertisements for catalogers in the United States and the United Kingdom from March 1995 through February 1996. Of the 2,700 position openings studied, he found that 147 advertised cataloging as the primary job duty for domestic academic positions and that 143 combined cataloging with other duties. ${ }^{3}$ Several other studies investigated even more specialized positions, including collection development librarians, serials librarians, and serials catalogers. ${ }^{4}$

\section{This aging librarian demographic has yet to impact the academic library job market as a whole.}

The advent of systems and automation librarian positions in the past few decades has afforded an opportunity for several interesting research studies. Among these are John M. Budd's article investigating requirements and benefits of automation librarians in 1988, and Margaret Foote's survey of systems librarian openings in academic libraries from 1990 through $1994 .{ }^{5}$ Other studies used content analysis of advertisements in an effort to document the impact of automation on academic librarians. Yuan Zhou reported on the increased demand for computer-related skills for academic librarians from 1974 to
1994. ${ }^{6}$ Hong Xu analyzed twenty years of position announcements (1971-1990) to investigate the impact of technology on cataloging and reference librarians. ${ }^{7}$

Mary Baier Wells and Ronald Rayman also tracked advertisements over an extended period of time in an effort to determine trends in the academic library job market. Wells provided a needed first step by sampling job advertisements for academic librarians at five-year intervals, between 1959 and 1979. ${ }^{8}$ Rayman investigated job vacancies annually from 1970 through 1979. ${ }^{9}$ Both Wells and Rayman analyzed multiple position titles, providing a historical perspective to the topic. No other significant studies investigated a range of years for multiple position titles. Reser and Schuneman, however, performed an in-depth analysis of public and technical services positions for $1988 .{ }^{10}$ The purpose of this study is to report on the status of the market in the mid-1990s and, through comparison to Reser and Schuneman and others, to identify potential trends in the market and update findings between 1988 and 1996. The hypotheses tested in this study are:

- Electronic services jobs are more likely to require computer skills.

- Technical services jobs are more likely to require foreign-language skills.

- Technical services jobs are more likely to require previous work experience.

- Electronic services jobs are less likely to require an ALA MLS.

- Public services jobs are more likely to require advanced subject degrees.

- Electronic services jobs are more likely to advertise higher salaries.

- Increased experience is more likely to advertise higher salaries.

\section{Methodology}

To identify changes in the academic library job market between 1988 and 1996, the authors reviewed academic library position announcements published in 1996 in American Libraries, Chronicle of Higher Education, College \& Research Libraries News, and Library Journal. These jour- 
nals were selected for breadth of job advertisements and consistency in data collection as they were the same titles used to procure 1988 data. Positions advertised on listservs, on Web sites, and in regional or local publications were not included in this survey.

After collecting advertisements, all duplicate postings were removed (jobs found in more than one journal or more than one sequential issue of the same journal), as were part-time appointments or those of less than one year. Advertisements for dean and director positions also were eliminated. Only four-year academic institutions located in the United States were retained. In the event the posting involved a split assignment (wherein the vacancy had responsibilities under two or more job titles), the position with the largest percentage of duties was classified. If not stated in the advertisement, the job title described first was coded.

The authors then coded each advertisement into various classifications according to the schema devised by Reser and Schuneman. The categories included type of position, geographic region of the institution, presence of administrative duties, computer skills, language skills, previous work experience, educational level, and salary. ${ }^{11}$ Three people coded thirty advertisements to measure inter-rater reliability. The tests revealed some discrepancy among the raters' assignment of category classification. To compensate, two raters coded specific categories of each announcement. The third rater entered the data into a spreadsheet and checked for consistency of coding. Forms were analyzed with Excel and Statistical Analysis Software (SAS) programs. Statistical tests included chi-square and Analysis of Variance (ANOVA). Results of the analysis of the 1996 data were then compared to the 1988 findings reported by Reser and Schuneman.

\section{Results}

Recent projections regarding growth in the library employment market range from dismal to dynamic. Based on eco- nomic indicators or the growth of technology, researchers foresaw slow expansion or declining opportunities in the field. ${ }^{12}$ Stanley J. Wilder, on the other hand, postulated that library jobs would grow over the next twenty-five years due to retirements by an aging librarian population. ${ }^{13}$ This aging librarian demographic has yet to impact the academic library job market as a whole. Instead of an increase in advertised openings, this study found a significant decrease when compared to 1988 data. Nine hundred unique positions were identified for 1996, compared to 1,133 reported by Reser and Schuneman, a decrease of more than 20 percent. ${ }^{14}$

As table 1 shows, reference, at 30.2 percent, accounted for the largest number of positions advertised. Cataloging, at 12.8 percent, constituted the next largest category, a decrease of more than 10 percent from 1988. Reference and cataloging positions also comprised the two largest categories in the 1988 study, accounting for 49.4 percent and 22.9 percent of the pool, respectively. ${ }^{15}$

The number of job titles analyzed within the public services division increased from six in 1988 to eleven in 1996. Branch managers, collection development, government documents, music, and special collections positions were advertised at such frequency as to warrant their own categories and were added to the positions of reference, head of public services, instruction, circulation, interlibrary loan (ILL), and other public services as reported by Reser and Schuneman. ${ }^{16}$ The number of job titles under technical services was the same in both studies.

Due to the growing rate of electronic services positions advertised in the 1980s, and the firm entrenchment of the systems and automation librarian in the field, the authors expanded Reser and Schuneman's divisions of public services and technical services to include electronic services. As a result, five additional job titles (systems librarian, head of systems, electronic public services librarian, electronic technical services librarian, and other electronic ser- 
TABLE 1

Positions Advertised, by Job Title

\begin{tabular}{lrr} 
Job Title & No. & \% \\
\hline Reference & 272 & 30.2 \\
Head, Public Services & 28 & 3.1 \\
Branch & 18 & 2.0 \\
Circulation & 18 & 2.0 \\
Collection Development & 54 & 6.0 \\
Government Documents & 20 & 2.2 \\
Interlibrary Loan & 14 & 1.6 \\
Library Instruction & 49 & 5.4 \\
Music & 4 & .4 \\
Special Collections & 44 & 4.9 \\
Other & 28 & 3.1 \\
\hline \multicolumn{1}{|c}{ Total Public Services } & $\mathbf{5 4 9}$ & $\mathbf{6 0 . 9}$ \\
Cataloging & 115 & 12.8 \\
Head, Technical Services & 21 & 2.3 \\
Acquisitions & 17 & 1.9 \\
Serials & 18 & 2.0 \\
Preservation & 12 & 1.3 \\
Other & 16 & 1.8 \\
\hline \multicolumn{1}{c}{ Total Technical Services } & $\mathbf{1 9 9}$ & $\mathbf{2 2 . 1}$ \\
Systems & 39 & 4.3 \\
Head, Electronic Services & 12 & 1.3 \\
Electronic/Tech Services & 17 & 1.9 \\
Electronic/Public Services & 61 & 6.8 \\
Other & 23 & 2.6 \\
\hline \multicolumn{1}{|c}{ Total Electronic Services } & $\mathbf{1 5 2}$ & $\mathbf{1 6 . 9}$ \\
\hline \hline Totals & $\mathbf{9 0 0}$ & $\mathbf{9 9 . 9}$ \\
\hline
\end{tabular}

Comparing these data to the 1988 data revealed relative stasis in public services, but a marked decrease, from 38.5 to 22.1 percent, in technical services job announcements. ${ }^{17}$

The geographic location of each position was coded to the state level. The states with the greatest number of advertised positions were Texas, with seventy-two (8\%) and New York, with sixty-eight (7.6\%). Neither Idaho nor Wyoming posted vacancies meeting the inclusion criteria for 1996. The states were divided into geographic regions defined by the ALA Survey of Librarian Salaries. ${ }^{18}$ As indicated in table 2, the number of job advertisements was fairly evenly distributed among the regions, with a high of 236 postings in the North Atlantic region and a low of 218 in the Southeast region. Although all regions experienced decreases, the North Atlantic and Midwest suffered the highest loss of advertised openings when compared to 1988 data.

Each position was analyzed for the presence of administrative duties, which were defined as the

vices) were included in the 1996 study. Systems positions were identified as those whose major responsibility involved working with an integrated library system. The job title of other electronic services was composed of those working primarily with compact discs, local area networks (LANs), and microcomputer software and hardware. A large portion of electronic public services and electronic technical services position responsibilities included maintaining and installing hardware and software, and/or developing a Web presence for their respective divisions or libraries.

The total number of job titles reviewed increased from twelve in 1988 to twentytwo in 1996. Of the nine hundred positions analyzed, 549 (61\%) were public services, 199 (22.1\%) were technical services, and 152 (16.9\%) were electronic services. head or assistant head of a unit, department, section, etc. Administrative responsibilities were found in 22.4 percent of positions advertised, a decrease from 39 percent in 1988. The breakdown by division revealed that 34.7 percent of technical services positions contained administrative duties, a decrease from 45 percent in $1988 .{ }^{19}$ In contrast, 20.2 percent of public services and 14.5 percent of electronic services positions included administrative responsibilities. This suggests that although there is a marked decrease in the number of positions advertising administrative duties, persons working in technical services are still more likely to have administrative responsibilities as part of their regular job duties.

Findings regarding computer skills, foreign languages, previous work expe- 


\section{TABLE 2}

Positions Advertised, by Region

\begin{tabular}{lccc} 
Region & No. & $\mathbf{9}$ & Change from 1988 Data \\
\hline North Atlantic & 236 & 26.2 & 90 loss \\
Midwest & 219 & 24.3 & 74 loss \\
Southeast & 218 & 24.2 & 21 loss \\
West & 227 & 25.2 & 48 loss \\
\hline Totals & $\mathbf{9 0 0}$ & $\mathbf{9 9 . 9}$ & $\mathbf{2 3 3 l o s s}$
\end{tabular}

"preferred" categories reveals even more similarity between public services and technical services, with 80.8 and 79.9 percent, respectively, requesting computer skills, as compared to electronic services (96\%) positions.

Data from 1996 revealed that 66.9 percent of all porience, educational requirements, and salary are reported in the following sections.

\section{Computer Skills}

As information sources in academic libraries are delivered increasingly via an electronic medium, the degree to which computer skills are sought by libraries becomes an important concern. Computer skill, as broadly defined by Reser and Schuneman, includes knowledge of, or experience with, a wide variety of computer applications. ${ }^{20}$

A small difference exists in the requirement of computer skills between public services $(62.8 \%)$ and technical services $(59.3 \%)$. When compared to electronic services positions, which required computer skills 91.4 percent of the time, these levels were found to be statistically significant (see table 3). Although this requirement is found in the majority of announcements among all divisions, the figures demonstrate a much greater demand for these skills among electronic services librarians, supporting the authors' hypothesis. Combining the "required" and sitions advertised required computer skills, compared to 40.5 percent reported by Reser and Schuneman. ${ }^{21}$ Not surprisingly, this comparison revealed that the demand for computer skills increased rapidly among all divisions.

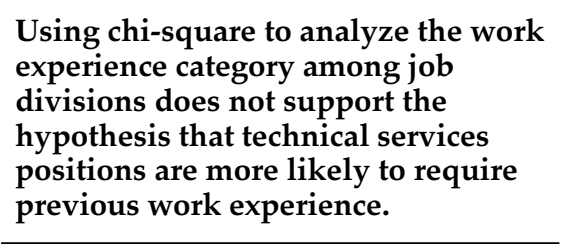

\section{Foreign Language}

Position advertisements also were examined for foreign-language requirements. Any mention of foreign-language skills, whether required or preferred, and the level of proficiency requested were coded. Technical services positions required or preferred foreign-language skills 30.7 percent of the time. Based on analysis of cataloging positions in the 1970s and 1980s, Furuta reported that foreign-language ability was requested in

TABLE 3

Computer Skills, by Division

\begin{tabular}{|c|c|c|c|c|c|c|c|c|}
\hline & \multicolumn{2}{|c|}{ Public Services } & \multicolumn{2}{|c|}{ Technical Services } & \multicolumn{2}{|c|}{ Electronic Services } & \multicolumn{2}{|c|}{ Total } \\
\hline & No. & $\%$ & No. & $\%$ & No. & $\%$ & No. & $\%$ \\
\hline Not stated & 105 & 19.1 & 40 & 20.1 & 6 & 3.9 & 151 & 16.8 \\
\hline Preferred & 99 & 18.0 & 41 & 20.6 & 7 & 4.6 & 147 & 16.3 \\
\hline Required & 345 & 62.8 & 118 & 59.3 & 139 & 91.4 & 602 & 66.9 \\
\hline Totals & 549 & 99.9 & 199 & 100.0 & 152 & 99.9 & 900 & 100.0 \\
\hline
\end{tabular}




\begin{tabular}{|c|c|c|c|c|c|c|c|}
\hline \multicolumn{8}{|c|}{$\begin{array}{c}\text { TABLE } 4 \\
\text { Foreign-Language Requirements, by Division } \\
\end{array}$} \\
\hline & \multicolumn{2}{|c|}{ Public Services } & \multicolumn{2}{|c|}{ Technical Services } & \multicolumn{2}{|c|}{ Electronic Services } & Total \\
\hline & No. & . $\%$ & No. & $\%$ & No. & . $\%$ & No. $\%$ \\
\hline Not stated & 470 & 85.6 & 138 & 69.3 & 145 & 95.4 & $753 \quad 83.7$ \\
\hline Preferred & 42 & 7.7 & 22 & 11.1 & 1 & .7 & $\begin{array}{ll}65 & 7.2\end{array}$ \\
\hline Required & 37 & 6.7 & 39 & 19.6 & 6 & 3.9 & 82 \\
\hline Totals & 549 & 100.0 & 199 & 100.0 & 152 & 100.0 & 900100.0 \\
\hline \multicolumn{8}{|c|}{$\mathrm{X} 2=43.37 ; \mathrm{df}=2 ; \mathrm{p}<0.0001$} \\
\hline
\end{tabular}

65 percent of the advertisements for academic libraries..$^{22}$ In a more recent study, Towsey noted that language skills were indicated in 44 percent of cataloging announcements. ${ }^{23}$ Even though foreignlanguage skills as a requirement for technical services positions apparently declined between the 1970s and 1990s, these positions were still more likely to require them than public or electronic services positions were. The request for foreign-language skills for cataloging positions is in contrast to public services positions and electronic services positions requiring or preferring them in 14.4 and 4.6 percent of advertisements, respectively (see table 4). Comparing the request for foreign-language skills in the 1996 and 1988 studies revealed percentages have remained fairly constant, with only a slight decrease for both technical services and public services positions, from 37 to 30.7 percent and from 16 to 14.4 percent, respectively. ${ }^{24}$

The 147 advertisements that requested foreign-language skills were further broken down by the level of language skill required-working, reading, and fluent (see table 5). Statistical analysis was not performed due to the small number of results reported. However, it is interesting to note that public services positions were more likely to request fluent knowledge of a foreign language whereas reading knowledge was more highly sought by electronic services and technical services.

\section{Work Experience}

Each job advertisement was analyzed to determine whether previous work experience was a prerequisite for employment. As in Reser and Schuneman's study, data on work experience were classified as "required," "preferred/desired," or "not stated or no work experience." ${ }^{25}$ Inclusion in the last category consisted of announcements that (1) did not mention work experience, (2) stated that no experience was necessary, or (3) were noted as "entry level."

Analysis of the 1996 data indicated that 20 percent of the position advertisements could be met by individuals with no pre-

\begin{tabular}{|c|c|c|c|c|c|c|c|c|}
\hline \multicolumn{9}{|c|}{$\begin{array}{c}\text { TABLE } 5 \\
\text { Language Skill Level, by Division } \\
\end{array}$} \\
\hline & \multicolumn{2}{|c|}{ Public Services } & \multicolumn{2}{|c|}{ Technical Services } & \multicolumn{2}{|c|}{ Electronic Services } & \multicolumn{2}{|c|}{ Total } \\
\hline & No. & $\%$ & No. & $\%$ & No. & $\%$ & No. & $\%$ \\
\hline Not stated & 34 & 43.0 & 21 & 34.4 & 1 & 14.3 & 56 & 38.1 \\
\hline Working & 18 & 22.8 & 15 & 24.6 & 2 & 28.6 & 35 & 23.8 \\
\hline Reading & 19 & 24.0 & 21 & 34.4 & 4 & 57.1 & 44 & 29.9 \\
\hline Fluent & 8 & 10.1 & 4 & 6.6 & 0 & 0.0 & 12 & 8.2 \\
\hline Totals & 79 & 99.9 & 61 & 100.0 & 7 & 100.0 & 147 & 100.0 \\
\hline
\end{tabular}




\begin{tabular}{|c|c|c|c|c|c|c|}
\hline \multicolumn{7}{|c|}{$\begin{array}{c}\text { TABLE } 6 \\
\text { Previous Work Experience, by Division }\end{array}$} \\
\hline & \multicolumn{2}{|c|}{ Public Services } & \multicolumn{2}{|c|}{ Technical Services } & Electronic Services & Total \\
\hline & No. & $\%$ & No. & $\%$ & No. $\%$ & No. $\%$ \\
\hline Not stated & 102 & 18.6 & 38 & 19.1 & $41 \quad 27.0$ & 18120.1 \\
\hline Preferred & 144 & 26.2 & 33 & 16.6 & $28 \quad 18.4$ & $205 \quad 22.8$ \\
\hline Required & 303 & 55.2 & 128 & 64.3 & $83 \quad 54.6$ & $514 \quad 57.1$ \\
\hline Totals & 549 & 100.0 & 199 & 100.0 & 152100.0 & 900100.0 \\
\hline
\end{tabular}

vious experience. Almost 23 percent of the advertisements listed library experience as preferred or desired, and 57.1 percent required some previous library experience (see table 6). These results show a pattern consistent with findings from the 1988 survey in which 18 percent of job postings could be met with no experience, 31 percent requested experience, and 51 percent required previous library experience. Differences decreased even more when combining the required and preferred/desired categories: 82 percent of job announcements from 1988 requested previous library experience, compared to almost 80 percent in 1996. ${ }^{26}$

Using chi-square to analyze the work experience category among job divisions does not support the hypothesis that technical services positions are more likely to require previous work experience. After combining required and preferred/desired variables, the data indicate that technical services and public services are about equal in their request of previous work experience at about 81 percent each. Electronic services, at 73 percent, are below public services and technical services.

\section{Educational Requirements}

Studies tracking the requirement of an ALA-accredited degree in library science for professional positions have reported more than 90 percent of academic, public, and special library job advertisements consider it a requirement for employment. ${ }^{27}$ Reser and Schuneman found that 98 percent of job announcements in 1988 required an ALA-accredited library degree, but this requirement was present in only 90.6 percent of job advertisements posted in $1996 .{ }^{28}$

When analyzing this requirement among job divisions, even more variability is revealed. Public services and technical services jobs advertised in 1996 sought the ALA-accredited MLS 93.4 and 93.5 percent of the time, respectively. Although hypothesized that electronic services positions would be less likely to require the ALA-MLS, the authors were surprised to find it requested only 76.3 percent of the time.

Significant differences also were found when considering requirements for advanced degrees (subject master's, law, or doctoral). As expected, public services positions, at 35.4 percent, were approximately three times as likely to require or prefer advanced subject degrees when compared to technical services, at 10 percent of the time, and electronic services, at 13.8 percent of the time (see table 7). This is similar to 1988 data of when 30.7 percent of public services positions and 12.4 percent of technical services positions required or requested an advanced degree. ${ }^{29}$

\section{Minimum Salary}

Studies of librarian salaries traditionally used either minimum stated salaries or the midpoint of a stated range. For the purposes of this study, and for consistency in comparison to Reser and Schuneman's analysis, the authors coded the minimum salary stated in advertisements, whether a range was indicated or not. As pointed 


\begin{tabular}{|c|c|c|c|c|c|c|c|}
\hline \multicolumn{8}{|c|}{$\begin{array}{l}\text { TABLE } 7 \\
\text { Advanced Degree Requirements, by Division } \\
\end{array}$} \\
\hline & \multicolumn{2}{|c|}{ Public Services } & \multicolumn{2}{|c|}{ Technical Services } & \multicolumn{2}{|c|}{ Electronic Services } & Total \\
\hline & No. & $\%$ & No. & $\%$ & No & $\%$ & No. $\%$ \\
\hline Not Stated & 355 & 64.7 & 179 & 90.0 & 131 & 86.2 & $665 \quad 73.9$ \\
\hline Preferred & 147 & 26.8 & 17 & 8.5 & 16 & 10.5 & $180 \quad 20.0$ \\
\hline Required & 47 & 8.6 & 3 & 1.5 & 5 & 3.3 & $55 \quad 6.1$ \\
\hline Totals & 549 & 100.1 & 199 & 100.0 & 152 & 100.0 & 900100.0 \\
\hline \multicolumn{8}{|c|}{$\mathrm{X} 2=62.33 ; \mathrm{df}=2 ; \mathrm{p}<0.0001$} \\
\hline
\end{tabular}

out by Reser and Schuneman, limitations exist with salary analyses. They noted that salaries stated in advertisements are generally open to negotiation and that actual starting salaries may be higher. Further, they cautioned that advertised salaries should not be compared to salary data, which are published in annual surveys and based on actual salaries. Finally, they noted that nonwage benefits have not been accounted for and also should be considered by the job seeker. $^{30}$

The lowest and highest advertised individual salaries were both in public services, ranging from $\$ 19,157$ to $\$ 65,000$. The mean of all salaries was $\$ 30,945$, and the standard deviation was $\$ 6,421$. Of advertised minimum salaries, 86.8 percent fell within a normal distribution (see table 8).

As expected, electronic services jobs were more likely to advertise higher salaries. For 1996, the mean salary for electronic services positions was $\$ 1,700$ higher than technical services positions and $\$ 1,831$ higher than public services (see table 9).

Experience in relation to advertised salaries also was investigated. As hypothesized, job announcements requiring experience were more likely to advertise higher salaries than announcements that did not. Oddly, positions that preferred experience differed only slightly in salary from entrylevel positions (see table 10).

To make comparisons among public, technical, and electronic divisions more

\begin{tabular}{|lrc|}
\hline \multicolumn{3}{|c|}{ TABLE 8} \\
\multicolumn{3}{|c}{$\begin{array}{c}\text { Mean Minimum Salaries, by Position } \\
\text { (In Descending Order) }\end{array}$} \\
\hline \hline Position & No. & Mean Salary (\$) \\
\hline Head, Technical Services & 21 & 41,500 \\
Head, Public Services & 28 & 41,113 \\
Head, Electronic Services & 12 & 40,750 \\
Branch Manager & 18 & 35,012 \\
Special Collections & 44 & 34,360 \\
Electronic/Technical Services & 17 & 33,430 \\
Other, Systems & 23 & 32,192 \\
Collection Development & 54 & 31,845 \\
Systems & 39 & 31,772 \\
Electronic/Public Services & 61 & 30,813 \\
Cataloging & 115 & 30,774 \\
Other, Public Services & 28 & 30,348 \\
Circulation & 18 & 30,311 \\
Other, Technical Services & 16 & 30,179 \\
Instruction & 49 & 29,837 \\
Music & 4 & 29,650 \\
Government Documents & 20 & 29,312 \\
Preservation & 12 & 29,304 \\
Acquisitions & 17 & 29,206 \\
Reference & 272 & 29,033 \\
ILL & 14 & 28,881 \\
Serials & 18 & 28,814 \\
& & \\
\hline
\end{tabular}




\begin{tabular}{|lcc|}
\hline \multicolumn{3}{|c|}{ TABLE 9 } \\
Mean Salary, by Job Division \\
\hline \hline Job Division & Salary (\$) & Standard Deviation (\$) \\
\hline Public Services & 30,620 & 6,518 \\
Technical Services & 30,751 & 5,992 \\
Electronic Services & 32,451 & 6,429 \\
& & \\
$\mathrm{f}=3.46 ; \mathrm{df}=2 ; \mathrm{p}=0.03$ & \\
\hline
\end{tabular}

analysis of nine hundred position announcements and their comparison to earlier research. First is the significant decrease in the volume of advertised positions and the shift in types of positions advertised. Decreases were concentrated mainly in technical ser-

meaningful, three subgroups from each division were identified and compared (see table 11). Reser and Schuneman chose to analyze reference and cataloging positions because they comprised the largest segment within their respective divisions. They went on to analyze these positions with and without administrative duties and as heads of departments due to their representation of a logical career progression. ${ }^{31}$ The authors likewise used Reser and Schuneman's pairings, with the addition of systems positions.

In comparison to 1988 findings, where salaries for reference and cataloging positions without administrative duties were almost identical, 1996 data indicate that cataloging salaries were almost $\$ 1,000$ greater than reference. The difference between systems without administrative duties compared to reference and cataloging positions was even more substantial, $\$ 3,719$ and $\$ 2,823$, respectively. Due to the small number of systems advertisements with administrative responsibilities (one announcement), reporting is less reliable. However, reference positions with administrative duties paid $\$ 1,794$ more than cataloging on the average. For division heads, the mean minimum salary for technical services heads was only $\$ 387$ more than public services and $\$ 750$ more than division heads in electronic services.

\section{Discussion}

Several conclusions can be drawn from this vices, with cataloging experiencing the most dramatic loss in job announcements. Other researchers have likewise reported a reduction in professional cataloging staff. ${ }^{32}$ Wilder's analysis of librarian demographics suggested that this may be due to catalogers being an unusually old subgroup of librarians who are at the forefront of the retirement wave. ${ }^{33}$ Others attributed the decrease in numbers to the impact of automation and bibliographic utilities on cataloging positions. ${ }^{34}$ It is possible that as many catalogers retire, libraries are choosing not to rehire those positions and, instead, are meeting their needs by using paraprofessionals, outsourcing, or using bibliographic utilities.

In contrast to the decrease in the number of technical services positions advertised, specialist positions appear to be growing. ${ }^{35}$ This is further evidenced by the increase in the number of position titles analyzed over time. In a study spanning twenty years of job advertisements, Wells classified position advertisements into nine different job titles. ${ }^{36}$ Reser and Schuneman assigned positions to twelve job titles for their analysis of 1988 adver-

\begin{tabular}{|lcc|}
\hline \multicolumn{3}{|c|}{ TABLE 10 } \\
Mean Salary, by Level of Experience \\
\hline \hline Experience Level & Salary (\$) & Standard Deviation (\$) \\
\hline Entry & 28,971 & 4,681 \\
Preferred & 28,090 & 3,996 \\
Required & 32,875 & 7,102 \\
& & \\
$\mathrm{f}=42.56 ; \mathrm{df}=2 ; \mathrm{p}<0.0001$ & \\
\hline
\end{tabular}




\begin{tabular}{|llrrrr|}
\hline \multicolumn{5}{c|}{ TABLE 11 } \\
Salary Comparisons & & \\
\hline \hline Title & & No. & Rpt'd & $\begin{array}{c}\text { Mean } \\
\text { Salary (\$) }\end{array}$ & $\begin{array}{c}\text { Standard } \\
\text { Deviation (\$) }\end{array}$ \\
\hline Set 1 & Head, Public Services & 28 & 17 & 41,113 & 11,498 \\
& Head, Technical Services & 21 & 6 & 41,500 & 11,559 \\
& Head, Electronic Services & 12 & 10 & 40,750 & 8,626 \\
Set 2 Reference (with admin. duties) & 30 & 24 & 36,791 & 6,667 \\
& Cataloging (with admin. duties) & 33 & 25 & 34,997 & 6,275 \\
& Systems (with admin. duties) & 3 & 1 & 33,000 & 0 \\
Set 3 Reference (no admin. duties) & 242 & 179 & 27,992 & 3,793 \\
& Cataloging (no admin. duties) & 82 & 56 & 28,888 & 3,640 \\
& Systems (no admin. duties) & 36 & 20 & 31,711 & 5,708 \\
\hline
\end{tabular}

tisements. ${ }^{37}$ For this study, there were enough distinct advertised positions to be coded into twenty-two different job titles. William C. Robinson, who reviewed collection development positions over an eleven-year period, reported that the number of positions announced nearly doubled throughout the 1980s. ${ }^{38}$ Other researchers have indicated a trend toward growing numbers of job advertisements for specialized positions. ${ }^{39}$

The growing request for computer skills constitutes another trend. More than 83 percent of position announcements in this study requested computer skills, an increase of 13 percent in eight years. ${ }^{40}$ Earlier researchers likewise have indicated the growing demand for computer and electronic skills across all job titles. Yuan Zhou, tracking the demand for computer-related skills for academic librarians, found that the number of advertisements requesting these skills grew from 10.3 percent in 1974 to 88.9 percent in $1994 .{ }^{41}$ Hong Xu reported that computer skills requirements increased dramatically for reference and cataloging positions throughout the 1970s and 1980s. ${ }^{42}$ Perhaps this burgeoning need for electronically savvy candidates has contributed to what may be the most dramatic trend - an increase in the acceptance of degrees other than the ALA-accredited MLS. In 1988, Phyllis J. Hudson stated that "the ALA-accredited MLS degree is universally recognized as the basic requirement for entry into academic librarianship." 43 However, this no longer appears to be a universal truth. There is a definite trend toward the use of non-MLSdegreed professionals to fill systems positions. Although public and technical services positions continue to require the ALA-accredited library degree in well over 90 percent of job advertisements, this qualification was present in only three-fourths of the electronic services advertisements. Other researchers have related similar results. Budd reported that 21.4 percent of the systems announcements he analyzed accepted a degree other than the ALA-accredited MLS, and Foote stated that more than one-third of the advertisements she reviewed did not require the ALA library degree. ${ }^{44}$

Although libraries face a shortage of qualified applicants for systems positions, several researchers found the relaxing of this requirement unsettling. ${ }^{45}$ As stated by Foote, "less frequent demand for the MLS could erode the professional status of librarians in this age of information technology." ${ }^{46}$ It is imperative that the systems librarian have a clear understanding of how information flows into the library and how colleagues and patrons use this information. For many systems, it is more important to have a systems librarian with a thorough grounding in the functions and organization of the library than in-depth knowledge of automation. ${ }^{47}$ One possible solution is to train promising librarians in the field of systems rather than 
programmers or analysts in the field of librarianship..$^{48}$ It also is possible that systems librarians who have held other positions may have more loyalty to the profession and stay in the job longer. The investment in training may outweigh the significant costs of replacing an employee.

\section{Suggestions for Further Research}

The primary purpose of this study was to determine if statistically significant differences exist among public services, technical services, and electronic services positions in academic libraries. Of equal importance, however, was the comparison of 1996 data to earlier research. The actual number of advertised positions decreased substantially between 1988 and 1996. Academic library positions appear to be becoming more specialized, and many requisite skills of these positions are changing rapidly and dramatically. The masthead of the profession, the ALA-accredited MLS, is in danger of being relinquished in the face of hard-to-fill systems positions. Further research designed to investigate benefits and qualifications of academic library positions and identify trends in the academic library job market is essential. Specifically, replication of Reser and Schuneman's study on an interval basis will control for fluctuations in the library job market and build on existing data. Library school administrators and professors must have a clear understanding of what qualifications are being sought to better prepare students for the job market. This research also will offer librarians and students a framework they can use to make informed choices when pursuing a specialization or a position in an academic library.

\section{Notes}

1. David W. Reser and Anita P. Schuneman, "The Academic Library Job Market: A Content Analysis Comparing Public and Technical Services," College \& Research Libraries 53 (Jan. 1992): 49-59.

2. Kenneth Furuta, "The Impact of Automation on Professional Catalogers," Information Technology and Libraries 9 (Sept. 1990): 242-52.

3. Michael Towsey, "Nice Work If You Can Get It? A Study of Patterns and Trends in Cataloguing Employment in the USA and the UK in the Mid-1990s," Cataloging and Classification Quarterly 24, nos. 1-2 (1997): 61-79.

4. Ann W. Copeland, "The Demand for Serials Catalogers: An Analysis of Job Advertisements, 1980-1995," Serials Librarian 32, nos. 1-2 (1997): 27-37; Carolyn J. Mueller and Margaret V. Mering, "Serials Positions in U.S. Academic Libraries, 1980-1988: ASurvey of Position Announcements," Library Resources and Technical Services 35 (Oct. 1991): 416-21; William C. Robinson, "Academic Library Collection Development and Management Positions: Announcements in College \& Research Libraries News from 1980 through 1991," Library Resources and Technical Services 37 (Apr. 1993): 134-46.

5. John M. Budd, "Salaries of Automation Librarians: Positions and Requirements," Journal of Library Administration 13, nos. 1-2 (1990): 21-29; Margaret Foote, "The Systems Librarian in U.S. Academic Libraries: A Survey of Announcements from College $\mathcal{E}$ Research Libraries News, 1990-1994," College E Research Libraries 58 (Nov. 1997): 517-26.

6. Yuan Zhou, "Analysis of Trends in Demand for Computer-Related Skills for Academic Librarians from 1974 to 1994," College \& Research Libraries 57 (May 1996): 259-72.

7. Hong $\mathrm{Xu}$, "The Impact of Automation on Job Requirements and Qualifications for Catalogers and Reference Librarians in Academic Libraries," Library Resources and Technical Services 40 (Jan. 1996): 9-31.

8. Mary Baier Wells, "Requirements and Benefits for Academic Librarians: 1959-1979," College \& Research Libraries 43 (Nov. 1982): 450-58.

9. Ronald Rayman, "Employment Opportunities for Academic Librarians in the 1970s: An Analysis of the Past Decade," College \& Research Libraries 42 (May 1981): 229-34.

10. Reser and Schuneman, "The Academic Library Job Market."

11. Ibid., 50.

12. U.S. Department of Labor, Bureau of Labor Statistics, Occupational Outlook Handbook, 1996/ 97 (Washington, D.C.: Government Printing Office, 1997); Rayman, “Employment Opportunities for Academic Librarians in the 1970s," 233.

13. Stanley J. Wilder, The Age Demographics of Academic Librarians: A Profession Apart (Wash- 
ington, D.C.: ARL, 1995). This report is based on data from the ARL Annual Salary Survey.

14. Reser and Schuneman, "The Academic Library Job Market," 50.

15. Ibid.

16. Ibid., 51.

17. Ibid.

18. American Library Association, Office for Research and Office for Library Personnel Resources, ALA Survey of Librarian Salaries 1995 (Chicago: ALA, 1995).

19. Reser and Schuneman, "The Academic Library Job Market," 51. Reser and Schuneman reported that 46 percent of technical services position advertisements had some type of administrative duties.

20. Ibid.

21. Ibid., 52.

22. Furuta, "The Impact of Automation on Professional Catalogers," 250.

23. Towsey, "Nice Work If You Can Get It?" 70.

24. Reser and Schuneman, "The Academic Library Job Market," 62.

25. Ibid., 53.

26. Ibid., 54 .

27. Wells, "Requirements and Benefits for Academic Librarians," 453; Holly Williams, "Required and Preferred Qualifications in Entry-Level Library Position Announcements," Mississippi Libraries 61 (winter 1997): 89-91; Joyce C. Wright, "Job Opportunities for Academic and Public Librarians: 1980-1984," Journal of Library Administration 9, no. 2 (1988): 45-58.

28. Reser and Schuneman, "The Academic Library Job Market," 54.

29. Ibid.

30. Ibid., 55 .

31. Ibid., 56 .

32. For example, Wells, "Requirements and Benefits for Academic Librarians," 453; Wilder, The Age Demographics of Academic Librarians, viii; $\mathrm{Xu}$, "The Impact of Automation on Job Requirements," 242.

33. Wilder, The Age Demographics of Academic Librarians, x.

34. For example, Furuta, "The Impact of Automation on Professional Catalogers," 242; Peter Spyers-Duran, "The Effects of Automation on Organizational Change, Staffing, and Human Relations in Catalog Departments," in Requiem or the Card Catalog: Management Issues in Automated Cataloging, ed. Daniel Gore, Joseph Kimbrough, and Peter Spyers-Duran (Westport, Conn.: Greenwood, 1979), 29-39; Xu, "The Impact of Automation on Job Requirements," 11.

35. Ellen Gay Detlefson, "Specialists as Professionals in Research Libraries: An Overview of Trends and an Analysis of Job Announcements," Library Trends 41 (fall 1992): 187-97; Furuta, "The Impact of Automation on Professional Catalogers," 251.

36. Wells, "Requirements and Benefits for Academic Librarians," 453.

37. Reser and Schuneman, "The Academic Library Job Market," 51.

38. Robinson, "Academic Library Collection Development and Management Positions," 137.

39. Copeland, "The Demand for Serials Catalogers," 33; Mueller and Mering, "Serials Positions in U.S. Academic Libraries," 419.

40. Reser and Schuneman, “The Academic Library Job Market," 52. Reser and Schuneman reported that 70.6 percent of ads required or preferred computer skills.

41. Zhou, "Analysis of Trends in Demand for Computer-Related Skills," 262.

42. Xu, "The Impact of Automation on Job Requirements," 23.

43. Phyllis J. Hudson, "Recruitment for Academic Librarianship," in Librarians for the New Millennium, ed. William E. Moen and Kathleen M. Hein (Chicago: ALA, 1988), 72-82.

44. Budd, "Salaries of Automation Librarians," 25; Foote, "The Systems Librarian in U.S. Academic Libraries," 522.

45. Felix Tse-Hsiu Chu, "Evaluating the Skills of the Systems Librarian," Journal of Library Administration 12, no. 1 (1990): 91-102; Detlefson, "Specialists as Professionals in Research Libraries," 195-196; Foote, "The Systems Librarian in U.S. Academic Libraries," 525.

46. Foote, "The Systems Librarian in U.S. Academic Libraries."

47. Susan Baerg Epstein, "Administrators of Automated Systems," Library Journal 116 (Mar. 15, 1991): 66-67.

48. Detlefson, "Specialists as Professionals in Research Libraries," 196; Susan K. Martin, "The Role of the Systems Librarian," Journal of Library Administration 9, no. 4 (1988): 57-68. 